\title{
A Note on the Particular Set with Size Three
}

\section{Piezīme par īpašo kopu ar izmēru trīs}

\author{
Özen Özer \\ Kırklareli University, Turkey
}

\begin{abstract}
For a fixed integer $k$, a $P_{k}$-set is defined as a set of $n$ positive integers $\left\{x_{1}, x_{2}, x_{3}, \ldots, x_{n}\right\}$ with the property that $x_{i} x_{j}+k$ is a perfect square, whenever $i \neq j$. In this paper, we prove $P_{11}=\{1,14,25\}, P_{-11}=\{1,15,36\}$ and $P_{-11}=\{4,9,23\}$ sets cannot be extendable. It is also proved that $P_{11}$ sets don't contain any multiple of 3 and $\boldsymbol{P}_{-11}$ sets don't include any multiple of 7 . Moreover, it is demonstrated that all of the elements of the sets $P_{-11}$ of size three cannot be odd positive integer.
\end{abstract}

Mathematics Subject Classifications: 11A07, 11D45, 11 A15.

Keywords - Congruences, $P_{k}$ sets, Pell's equations, Legendre symbol.

\section{INTRODUCTION AND PRELIMINARIES}

In the literature, the first paper related to simultaneous Pell's equations proved the unsolvability in terms of positive integers for the basic equation system in 1904. Simultaneous Pell's equations have been studied by most scholars, for example, Anglin, Baker, Davenport, Cohn, Mohanty, Ramasamy, Pinch, Ponnudurai, Tzanakis, etc.

Anglin [1] presented a method for solving a system of Pell's equations with the parameters absolutely less than 1000 . In 1969, Baker and Davenport [2] provided a set $\{1,3,8,120\}$ of size four. Many authors also applied the Baker-Davenport method to investigate similar problems. Tzanakis [13] suggested a method (elliptic logarithm method) using elliptic curves and linear forms in elliptic logarithms. In [8], an elliptic logarithm method was partially described by Katayama too.

On the other hand, some authors studied the number of solutions of simultaneous Pell's equations. Kanagasabapathy and Ponnudurai [7] dealt with the non-extendibility of $P_{-1}=\{1,5,10\}$ and the non-extendibility of $P_{-1}=\{1,2,7\}$ proven by Thamotherampillai. Brown [3] proved if $k \equiv 2$ (mod 4) then there was not $P_{k}$ set of size 4, and gave some results on $P_{k}$ if $k \equiv 5(\bmod 8)$.

In [11], Mohanty and Ramasamy introduced the concept of characteristic number of two simultaneous Pell's equations for a set of Pell's equations, including any square free positive integer number.

Recently, Gopalan and his co-authors have discussed some special non-extendable sets with size three. Filipin, Fujita and Mignotte [4] obtained significant results on the nonextendibility of some parametric families of $P_{-1}$ sets with size three.
Let $k$ be an integer. A $P_{k}$-set of size $m$ is a set $B=\left\{x_{1}, x_{2}, x_{3}, \ldots, x_{m}\right\}$ of distinct positive integers for which $x_{i} x_{j}+k$ is the square of an integer, whenever $i \neq j$. If there exist a positive integer $n \notin B$ such that $B \cup\{n\}$ is still a $P_{k}$-set, then the $P_{k}$-set $B$ can be extended. For example, $P_{-1}=\{1,2,7\}$ set of size $3, P_{1}=\{1,3,8,120\}$ set of size 4 etc.

One would like to have generalization of at least two methods for $P_{k}$ set. The first one is a general $D$, which governs the Pell's equation on hand and the other is a general prime number or a product of primes employed in the residue classes leading to the determination of quadratic characters.

In this research, we will prove that the sets $P_{11}=\{1,14,25\}$, $P_{-11}=\{1,15,36\}$ and $P_{-11}=\{4,9,23\}$ cannot be extended by using the second method. Also, we will demonstrate some properties of $P_{11}$ and $P_{-11}$ sets. Besides, it is proven that sets $P_{-11}$ cannot include three different odd positive integers as an element. This work also is similar to [9].

At the end of this section we will give the preliminary results obtained by our method. First, we recall some definitions and theorems as follow:

Definition 1.1. ([12]) If $n \in N$ and $n \in Z$ with $\operatorname{gdc}(a, n)=1$, then $a$ is a quadratic residue modulo $n$ if there is an integer $x$ such that $x^{2} \equiv a(\bmod n)$, and if the equivalence has no such solution, then $a$ is a quadratic nonresidue modulo $n$.

Definition 1.2. ([12]) If $c \in Z$ and $p>2$ is prime, then

$$
\left(\frac{c}{p}\right)=\left\{\begin{array}{l}
0, \text { if } p / c \\
1, \text { if } c \text { is quadratic residue } \bmod p \\
-1, \text { otherwise }
\end{array}\right.
$$

and $\left(\frac{c}{p}\right)$ is called the Legendre symbol of $c$ with respect to $p$.

The following is a fundamental result of quadratic residuacity modulo $n$. This term means the determination of whether integer $n$ is a quadratic residue or a nonresidue modulo $n$.

Theorem 1.1. ([12]) (The Quadratic Reciprocity Law) If $p \neq q$ are odd primes, then

$$
\left(\frac{p}{q}\right)\left(\frac{q}{p}\right)=(-1)^{\frac{p-1}{2} \cdot \frac{q-1}{2}}
$$


where $(-)$ represents the Legendre symbol.

Theorem 1.2. ([12]) (The Quadratic Residuacity of 2 Modulo $p$ )

For any odd prime $p$,

$$
\left(\frac{2}{p}\right) \equiv(-1)^{\left(p^{2}-1\right) / 8}(\bmod p) .
$$

Theorem 1.3. ([12]) (Jacobi and Quadratic Congruences)

Let $n>1$ be an integer, $b \in Z$ with $\operatorname{gdc}(b, n)=1$ and $n=2^{a_{0}} \prod_{j=1}^{m} p_{j}^{a_{j}}$ the canonical prime factorization of $n$ where $a_{0} \geq 0$ and $a_{j} \in N$ for the distinct odd primes $p_{j}$, $j=1,2, \ldots, m$. Then

$$
x^{2} \equiv b(\bmod n)
$$

is solvable if and only if $\left(a / p_{j}\right)=1$ for all $j=1,2, \ldots, m$ and $a \equiv 1\left(\bmod \operatorname{gdc}\left(8,2^{a_{0}}\right)\right)$.

Theorem 1.4. ([12]) (The Reciprocity Law for the Jacobi Symbol)

If $m, n \in N$ are odd and relatively prime, then

$$
\left(\frac{m}{n}\right)\left(\frac{n}{m}\right)=(-1)^{\frac{m-1}{2} \cdot \frac{n-1}{2}} .
$$

\section{MAIN RESULTS}

Theorem 2.1. The set $P_{11}=\{1,14,25\}$ cannot be extended to $P_{11}$ set of size 4 .

Proof. Suppose that $P_{11}=\{1,14,25\}$ can be extended for any positive integer $d$. It means $\{1,14,25, d\}$ is $P_{11}$ set. We can find $x, y, z$ integers such that

$$
\begin{aligned}
d+11 & =x^{2} \\
14 d+11 & =y^{2} \\
25 d+11 & =z^{2}
\end{aligned}
$$

By dropping $d$ from (1) and (3) we obtain

$$
25 x^{2}-z^{2}=264 \text {. }
$$

In (4), we can write left side as difference of two squares since 25 is a perfect square

$$
(5 x-z)(5 x+z)=264 \text {. }
$$

Also 264 can be factorized finitely. Thus, integer solutions of (4) are obtained as follows:

$$
(x, z)=( \pm 7, \pm 31)
$$

or

$$
(x, z)=( \pm 5, \pm 19)
$$

Eliminating $d$ from (1) and (2) simultaneously we get

$$
14 x^{2}-y^{2}=143
$$

Using (5) solution and substituting $x^{2}=49$ into (7) we have $y^{2}=543$ where $y$ is not an integer solution.

In a similar way, substituting (6) solutions $\left(x^{2}=25\right)$ into (7), we obtain $y^{2}=207$. This shows that $y$ is not an integer for the solution of (7).

Thus, there is no such $d \in Z$ and the set $P_{11}=\{1,14,25\}$ cannot be extended.

Theorem 2.2. The set $P_{-11}=\{1,15,36\}$ is non-extendable.

Proof. We assume that the set $\{1,15,36, d\}$ is $P_{-11}$ for any positive integer $d$. If we use the definition set of $P_{-11}$, then we have

$$
\begin{array}{r}
d-11=x^{2} \\
15 d-11=y^{2} \\
36 d-11=z^{2}
\end{array}
$$

We have to find integers $x, y, z$ satisfying (8), (9) and (10). From (8) and (10) we get

$$
z^{2}-36 x^{2}=385
$$

and from (8) and (9)

$$
y^{2}-15 x^{2}=154
$$

By the same manner of the proof of Theorem 2.1 and factorizing (11) we get

$$
(z-6 x)(z+6 x)=385 .
$$

If we solve (13), we obtain $(x, z)=( \pm 32, \pm 193)$, $(x, z)=( \pm 6, \pm 41),(x, z)=( \pm 4, \pm 31)$ or $(x, z)=( \pm 2, \pm 23)$.

If we substitute $x^{2}=1024, x^{2}=36, x^{2}=16$ or $x^{2}=4$ into (12), then we obtain $y^{2}=15514, y^{2}=694, y^{2}=394$ or $y^{2}=214$, respectively. Thus, there is not any integer $y$ satisfying the values.

Hence, the set $P_{-11}=\{1,15,36\}$ is non-extendable.

Theorem 2.3. The set $P_{-11}=\{4,9,23\}$ is nonextendable.

Proof. We assume that the set $\{4,9,23, d\}$ is a $P_{-11}$ for any positive integer $d$. By considering the definition of the set $P_{-11}$, then we get

$$
\begin{aligned}
& 4 d-11=x^{2} \\
& 9 d-11=y^{2} \\
& 23 d-11=z^{2}
\end{aligned}
$$

We have to find integers $(x, y, z)$ holding (14), (15) and (16). From (14) and (15) we get 


$$
4 y^{2}-9 x^{2}=55
$$

and by using (14) and (16) we obtain

$$
4 z^{2}-23 x^{2}=209
$$

By the same manner of the proof of Theorem 2.2 and factorising (17) we get;

$$
(2 y-3 x)(2 y+3 x)=55
$$

If we solve (19), we $(x, y)=( \pm 9, \pm 14)$ or $(x, y)=( \pm 1, \pm 4)$. If we substituting $x^{2}=81$ or $x^{2}=1$ into the (18) then we get $z^{2}=518$ or $z^{2}=58$, consecutively. So, there isn't any integer $z$ holding the (18) equation.

Hence, the set $P_{-11}=\{4,9,23\}$ is nonextendable.

Theorem 2.4. There is no set $P_{11}$ obtains any multiple of 3 .

Proof. We assume that $m$ is an element of set $P_{11}$. If $3 t$ is also an element of set $P_{11}$ for $t \in Z$, then

$$
3 \mathrm{tm}+11=A^{2}
$$

has to satisfy for integer $A$. If we apply modulo 3 into the (20), we obtain

$$
A^{2} \equiv 2(\bmod 3)
$$

By using Theorem 1.2. and the Definition 1.2, we get

$$
\left(\frac{2}{3}\right) \equiv(-1)^{\frac{1}{8}\left(3^{2}-1\right)}=-1
$$

since 3 is odd prime number. This means that equation (20) is unsolvable, i.e. 2 is non quadratic residue $(\bmod 3)$. This is a contradiction.

Therefore, $3 t$ can not be an element of $P_{11}$ for $t \in Z$.

Theorem 2.5. There is no set $P_{-11}$ includes any multiple of 7.

Proof. In a similar manner, suppose that $r$ is an element of set $P_{-11}$, If $7 s,(s \in Z)$ is also an element of set $P_{-11}$ then

$$
7 r s-11=B^{2}
$$

has to satisfy for integer $B$. Applying modulo 7 of both sides, we have

$$
B^{2} \equiv 3(\bmod 7)
$$

We have to calculate Legendre symbol $\left(\frac{3}{7}\right)$ by using

Theorem 1.1 and Definition 1.2.

From Theorem 1.1, we obtain

$$
\left(\frac{3}{7}\right)\left(\frac{7}{3}\right)=(-1)^{\frac{3-1}{2} \cdot \frac{7-1}{2}}
$$

since 3 and 7 are odd primes. By substituting $\left(\frac{7}{3}\right)=\left(\frac{1}{3}\right)=1$ into the (25), we have

$$
\left(\frac{3}{7}\right)=-1
$$

which means that equation (23) is unsolvable. So $7 s$ can not be an element of $P_{-11}$ for $s \in Z$.

Theorem 2.6. All of the elements of a $P_{-11}$ set of size three can not be odd numbers.

Proof. We assume that all of the elements of a $P_{-11}$ set of size three are odd numbers. For $\{a, b, c\} \in P_{-11}$, $a \equiv 1,3(\bmod 4), b \equiv 1,3(\bmod 4)$ and $c \equiv 1,3(\bmod 4)$ hold. Then, we obtain

$$
\begin{aligned}
& a b-11=x^{2} \\
& a c-11=y^{2} \\
& b c-11=z^{2}
\end{aligned}
$$

We have to find integers $x, y, z$ satisfying (26), (27) and (28). By substituting $a \equiv 1(\bmod 4), b \equiv 1(\bmod 4)$ and $c \equiv 1(\bmod 4)$ into (26), (27) and (28), we get

$$
x^{2} \equiv 2(\bmod 4), y^{2} \equiv 2(\bmod 4)
$$

and

$$
z^{2} \equiv 2(\bmod 4)
$$

This is a contradiction since every perfect square of an integer satisfies only $A^{2} \equiv 0(\bmod 4)$ or $A^{2} \equiv 1(\bmod 4)$. By the same manner, we get contradictions for the other cases of $a \equiv 1,3(\bmod 4), b \equiv 1,3(\bmod 4)$ and $c \equiv 1,3(\bmod 4)$. So, there is no $P_{-11}$ set of size three that contains three odd numbers as an element by contradiction.

\section{CONCLUSION}

The problem of extendibility and characterisation of $P_{k}$ sets is a significant problem despite being old. There are many distinct methods to prove that problem.

In this paper, we have introduced a very simple method for assessing the extendibility of $P_{k}$ sets of three size for $k=-11$ or $k=11$. We have constructed three new non-extendable $P_{11}$ and $P_{-11}$ sets. We have also proven some properties of such sets using only elementary number theory. The present paper is advancement in this area.

\section{REFERENCES}

[1] W. S. Anglin, The queen of mathematics: An introduction to number theory, Dordrecht: Kluwer Academic Publishers, 1995. https://doi.org/10.1007/978-94-011-0285-8

[2] A. Baker and H. Davenport, "The equations $3 x^{2}-2=y^{2}$ and $8 x^{2}-7=z^{2}$," The Quarterly Journal of Mathematics, vol. 20, issue 1, pp. 129-137, 1969. https://doi.org/10.1093/qmath/20.1.129

[3] E. Brown, "Sets in Which $x y+k$ is Always a Square," Math. Comp., vol. 45, pp. 613-620, 1958 .

[4] A. Filipin, Y. Fujita, and M. Mignotte, "The non-extendibility of some parametric families of $\mathrm{D}(-1)$-triples," Q. J. Math., vol. 63, issue 3, pp. 605-621, 2012. https://doi.org/10.1093/qmath/har013 
[5] M. A. Gopalan, S. Vidhyalakshmi and S. Mallika, "Some special nonextendable Diophantine triples," Sch. J. Eng. Tech., vol. 2, pp. 159-160, 2014.

[6] C. M. Grinstead, "On a Method of Solving a Class of Diophantine Equations," Math. Comp., vol. 32, pp. 936-940, 1978. https://doi.org/10.1090/S0025-5718-1978-0491480-0

[7] P. Kanagasabapathy and T. Ponnudurai, "The Simultaneous Diophantine Equations $y^{2}-3 x^{2}=-2$ and $z^{2}-8 x^{2}=-7$ ", Quarterly Journal of Mathernatics, vol. 26, issue 1, pp. 275-278, Jan. 1975. https://doi.org/10.1093/qmath/26.1.275

[8] S. Katayama, "Several methods for solving simultaneous Fermat-Pell equations," J. Math. Tokushima Univ., vol. 33, pp. 1-14, 1999.

[9] K. Kaygısiz and H. Şenay, "Contructions of Some New Nonextandable $P_{k}$ Sets," International Mathematical Forum, vol. 2, no. 58, pp. 28692874, 2007.

[10] D. W. Masser and J. H. Rickert, "Simultaneous Pell Equations," Journal of Number Theory, vol. 61, issue 1, pp. 52-66, Nov. 1996. https://doi.org/10.1006/jnth.1996.0137

[11] P. Mohanty and A. M. S. Ramasamy, "The Simultaneous Diophantine Equations $5 y^{2}-20=x^{2}, 2 y^{2}+1=z^{2}$, Journal of Number Theory, vol. 18 , issue 3 , pp. $365-359,1984$ https://doi.org/10.1016/0022-314X(84)90068-4
[12] R. A. Mollin, Fundamental Number theory with Applications, 2nd ed. CRC Press, 2008. https://doi.org/10.1201/b15895

[13] N. Tzanakis, "Effective solution of two simultaneous Pell equations by the elliptic logarithm method," Acta Arithm., vol. 103, pp. 119-135, 2002. https://doi.org/10.4064/aa103-2-2

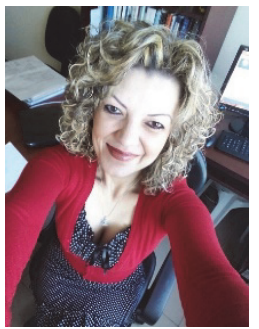

Özen Özer received her BSc and MSc degrees in Mathematics from Trakya University, Edirne (Turkey) and also Doctoral degree in Mathematics from Süleyman Demirel University, Isparta (Turkey), respectively. Currently, she works as an Assistant Professor at the Department of Mathematics at Kirklareli University. Her research includes the theory of real quadratic number fields with applications, fixed point theory, p-adic analysis, q-analysis.

E-mail: ozenozer39@gmail.com

Piezīme par īpašo kopu ar izmēru trīs

Özen Özer

Kirklareli Universitāte, Turcija

Veselam skaitlim $k$ piekārtotu $n$ veselu atšḳirīgu skaiț̣u kopu $\left\{x_{1}, x_{2}, x_{3}, \ldots, x_{n}\right\}$ sauc par $P_{k}$ kopu, ja $x_{i} x_{j}+k$ ir vesela skaiț̣a kvadrāts, ja vien $i \neq j, i, j \in N$. Uzskata, ka šādām kopām $P_{k}$ piemīt Diofanta īpašība. Uzdevums par kopu $P_{k}$ iegūšanas iespējām ir interesants, un tas pirmo reizi ir formulēts jau Diofanta laikā. Diofants pētīja kopu $P_{1}$ un ieguva četru pozitīvu, racionālu skaitḷu kopu, kurai piemīt Diofanta īpašība. Vēlāk pirmo pozitīvu veselu skaitḷu kopu ar Diofanta ìpašību ieguva Fermā. Pēe tam Beikers un Davenports parādīja, ka Fermā iegūtā kopa nav papildināma līdz pieciem elementiem, izmantojot iepriekšējo pieeju. Ir iegūti daži Beikera un Davenporta rezultātu vispārinājumi. Eksistē daudzas dažādas metodes, kuras demonstrē kopu $\boldsymbol{P}_{k}$, ja $\boldsymbol{k}>1$, eksistences neiespējamību. Ja Diofanta vienādojumā, proti, $x^{2}-d y^{2}=n, d$ ir vesels skaitlis, kā arī $x$ un $y$ ir veseli skaitḷi, tad to sauc par Pella vienādojumu. Ir daži īpaši gadījumi skaitlim $d$ Pella vienādojumā. Ja $d$ ir negatīvs, vienādojumam būs galīgs atrisinājumu skaits, ja $d$ ir pozitīvs, būs bezgalīgs atrisinājumu skaits. Šajā rakstā mēs ievedīsim l̦oti vienkāršu metodi, balstītu uz sadalīšanu $n$ reizinātājos, nepaplašināmām $P_{11}=\{1,14,25\}, P_{-11}=\{1,15,36\}$ un $P_{-11}=\{4,9,23\}$. Tad mēs pierādīsim, ka kopas $P_{11}=\{1,14,25\}, P_{-11}=\{1,15,36\}$ un $P_{-11}=\{4,9,23\}$ nevar tikt paplašinātas. Tiek arī parādīts, ka kopas $P_{11}$ nesatur pozitīvus reizinājumus ar trīs, kā arī, ka kopas $P_{-11}$ nesatur pozitīvus reizinājumus ar septiṇi. Vēl vairāk, ir parādīts, ka visi kopas $P_{-11}$ elementi, kuru izmērs trīs, nevar būt nepāra skaitlıi.

Atslēgas vārdi- Kongruence, kopa $P_{k}$, Lagranža simbols, Pella vienādojums. 